\title{
REVISITING BALANCE-OF-PAYMENTS CONSTRAINED GROWTH 70 YEARS AFTER ECALC'S MANIFESTO: THE CASE OF SOUTH AMERICA
}

\author{
Martín Abeles ${ }^{a}$ \\ Martín Cherkasky
}

\begin{abstract}
${ }^{a}$ Director of the Economic Commission for Latin America and the Caribbean (ECLAC) Office in Buenos Aires. Buenos Aires, BS, Argentina. ORCID: https://orcid.org/0000-0002-3809-7907.

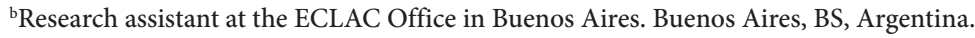
ORCID: https://orcid.org/0000-0002-4527-4940.
\end{abstract}

\begin{abstract}
In the period 2014-2018, South American economies experienced a low growth rate in a historical perspective and compared with other developing regions. The paper discusses the structural sources of recent macroeconomic performance in these countries, associated with their specialization on natural resources, inspired by Raúl Prebisch 1949 "Manifesto". It also poses that the increasing dependence on external borrowing as in the 2014-2018 period derived from the deepening of current account deficits could worsen growth constraints in the coming years, insofar as these financial flows do not contribute to a change in the productive structure, shifting the focus from export weakness to debt sustainability issues.
\end{abstract}

KEYWORDS: BOP-constrained growth; trade; debt; structural change; South America.

JEL CODES: F30; F41; F43; O54. 


\section{REVISITANDO A RESTRIÇÃO EXTERNA NOS 70 ANOS DO MANIFESTO DA CEPAL: O CASO DA AMÉRICA DO SUL}

RESUMO: Durante o período de cinco anos 2014-2018, as economias da América do Sul experimentaram uma baixa taxa de crescimento na perspectiva histórica e comparadas com outras regiões em desenvolvimento. Este artigo discute as fontes estruturais da dinâmica macroeconômica recente desses países, associada à sua especialização na exploração de recursos naturais, tomando como inspiração o "Manifesto" de 1949 por Raúl Prebisch. Afirma ainda que a maior dependência do endividamento externo do período 2014-2018, decorrente do aprofundamento dos déficits em conta corrente, poderia condicionar ainda mais o crescimento dos próximos anos, desde que esses fluxos financeiros não contribuam para uma mudança no a estrutura produtiva, voltando o foco das atenções da fragilidade das exportações para a sustentabilidade da dívida externa.

PALAVRAS-CHAVE: restrição externa; comércio; endividamento externo; mudança estrutural; América do Sul. 


\section{INTRODUCTION}

The economies of South America experienced a sharp slowdown in the last five years (2014-2018). Without counting Venezuela, the growth of countries in this part of the continent averaged 2.1\% between 2014 and 2018, compared to 5.7\% between 2004 and 2008, booming in the international prices of raw materials, and at a $5.3 \%$ between 2010 and 2013, the years of recovery after the international financial crisis. Even excluding Argentina and Brazil, which experienced several recessive episodes recently (Brazil in 2015 and 2016, Argentina in 2014, 2016 and 2018), the growth rate of the remaining countries in South America did not reach 3\% in 2014 and 2018, well below 5.5\% corresponding to the same subset of countries between 2004 and 2008, or 5.6\% in 2010-2013 (see Table 1). The only South American economies that managed to sustain a relatively high expansion rate were those of Bolivia and Paraguay (averaging $4.7 \%$ in 2004-2008, 5.6\% in 2010-2013, 4.4\% in 2014-2018), starting levels of gross domestic product (GDP) per capita below average and after certain structural transformations of strong macroeconomic impact (the nationalization of a significant portion of mining income in the case of Bolivia, the expansion of the border and agricultural productivity based on the exploitation of soybeans in the case of Paraguay).

Table 1 - South America (10 countries): growth rates, 2004-2018 (in \%, simple average)

\begin{tabular}{lccc}
\hline Countries & 2004-2008 & 2010-2013 & 2014-2018* $^{*}$ \\
\hline South America (10 countries) & 6.2 & 5.0 & 0.8 \\
South America (except Venezuela) & 5.7 & 5.3 & 2.1 \\
South America (except Argentina, Brazil and Venezuela) & 5.5 & 5.6 & 2.9 \\
\hline
\end{tabular}

Note: ${ }^{*}$ ) For the year 2018, ECLAC projections published in December 2018 are considered.

Source: Authors' elaboration based on CEPALSTAT and IMF World Economic Outlooks.

Excluding Bolivia and Paraguay, the pace of recent growth in the countries of South America is unsatisfactory, both from a historical perspective and compared to other regions of the developing world today, and it is in many cases less than it would be necessary to absorb the vegetative increase of the population. ${ }^{1}$ In this context, in

\footnotetext{
Between 1961 and 2013, for example, the average growth of the countries of South America was 3.7\% per year, and reached 4.7\% between 1961 and 1980, prior to the debt crisis (based on World Bank data and IMF data). In that period are the years of the Brazilian "miracle", with an average annual expansion rate of 8.9\% between 1968 and 1980, and the decade of greater continuity and intensity of growth in Argentine economic history, between 1964 and 1974, with an annual rate of 5.1\%. This little dynamism is also ma-
} 
recent years the previous positive trajectory in terms of employment generation and reduction of poverty and inequality has been moderated or reversed (ECLAC, 2019b), the investment rate tended to fall - which is still well below other developing regions - and the pace of productivity improvement remained stagnant (ECLAC, 2018).

How does one interpret this tendency to relative stagnation in this part of the region?

According to the orthodox viewpoint, this decline in the economic performance of Latin American countries in general (not only those in South America) is the product of a set of institutional deficiencies, among which imperfections or lack of depth in financial markets, the proliferation of distortive taxes, the excess or inadequacy of certain labor market regulations, and the oversizing of social protection systems. ${ }^{2}$ Those deficiencies, which would reveal the continuity of certain institutional mechanisms typical of the industrialization stage by import substitution (which did not become completely dismantled during the boom of market reforms), increase the legal uncertainty associated with the decisions of investment, generating a problem of appropriability that, always from the orthodox perspective, prevents the efficient allocation of resources. ${ }^{3}$

In this article, we would like to show how, to understand the recent trend towards the relative stagnation of the countries of the region, the structuralist perspective of a thinker such as Raúl Prebisch is more relevant than that proposed by the orthodox vision. The article focuses on the problem of external restriction to growth and its relationship with the economic structure, taking as inspiration the 1949 text (also known as the "ECLAC Manifesto") to which this special edition of REC pays tribute. The problem of the region is once again, as Prebisch suggested at that time, the (dynamic) insufficiency of a specialization based exclusively on the exploitation of natural resources. But the issue acquires specific features in recent decades, derived from the incursion of the logic of finance in the process of resource allocation (the phenomenon of financialization). ${ }^{4}$

nifested in relation to other developing regions at the time of writing this article, such as the Middle East and North Africa (excluding Libya and Yemen), which grew 2.8\% on average between 2014 and 2018, emerging Europe (3.2\%), or emerging Asian countries (4.6\%).

2 See, for example, Cavallo and Powell (2018).

3 The notion of efficiency implied in this perspective refers to the best use of static comparative advantages, which in South America, in general, are linked to natural resources. For a distinction between static efficiency (Ricardian) and dynamic efficiency (Schumpeterian and Keynesian), see ECLAC (2012).

4 For a discussion on the impact of this phenomenon in the region, see Abeles, Caldentey and Valdecantos (2018). 
As a recent ECLAC text states, from the moment in which international capital flows are deregulated, "the economic cycles began to be commanded mainly by the liquidity cycles of the international financial markets, rather than by the cycles of trade international " (ECLAC, 2018, p. 217, our translation). The specificity of this historical stage in Latin America and the Caribbean, particularly in South America, lies in the negative feedback between its productive specialization (based on the exploitation of natural resources) and a growing financial openness. The increased exposure to international liquidity cycles associated with this type of institutional arrangement weakens the investment process that would allow a progressive structural change, ${ }^{5}$ shortens the intended deadlines for making investments, and reinforces the pattern of existing specialization (lock-in). In the last five years, the expression of this type of institutional arrangement has been a growing external indebtedness, which was not accompanied by higher investment rates, nor by policies aimed at an effective change in the pattern of productive specialization.

The article is organized as follows. Section 1 analyzes the external restriction to growth faced by the countries of the region as a result of their commercial insertion and productive specialization patterns - one of the central problems analyzed by Prebisch in its 1949 text. With that purpose, we estimate the elasticities of foreign trade and the rate of maximum growth that a country can achieve in a manner consistent with external equilibrium in the long term, based on the condition or law of Thirlwall. Section 2 analyzes the additional restrictions on growth derived from the intensification of the external indebtedness process in recent decades. For this, a debt sustainability exercise is carried out, combining real and financing restrictions. In section 3, we present some final reflections.

\section{PRIMARY SPECIALIZATION AND EXTERNAL RESTRICTION}

The "ECLAC Manifesto" of 1949 is recognized, among other contributions, for exposing the hypothesis of the tendency to deteriorate the terms of trade for countries specialized in natural resources. The issue again raised some interest among analysts in the last stormy root of the rise in international prices of raw materials verified at the beginning of this century, which seemed to contradict that trend; a trend that, except for oil, had manifested as anticipated by Prebisch throughout the 20th century (see OCAMPO and PARRA, 2003).

\footnotetext{
5 We refer to the notion of progressive structural change in the sense proposed by ECLAC (2018).
} 
Apart from the historical (long-term) validity of what was later known as the Prebisch-Singer hypothesis, it is clear that the evolution of international prices of raw materials has had decisive gravitation effects on the short-term dynamics of the countries of South America. As can be seen in figure 1, the evolution of the South American GDP of the last and a half-decade is strongly correlated with that of international commodity prices, which fell 25\% between 2013 and $2018 .{ }^{6}$ This would explain, in a first approximation, the growth slowdown observed in the last five years. ${ }^{7}$

Figure 1 - Growth and exports in value in South America (nine countries) and raw materials price index, 2004-2018

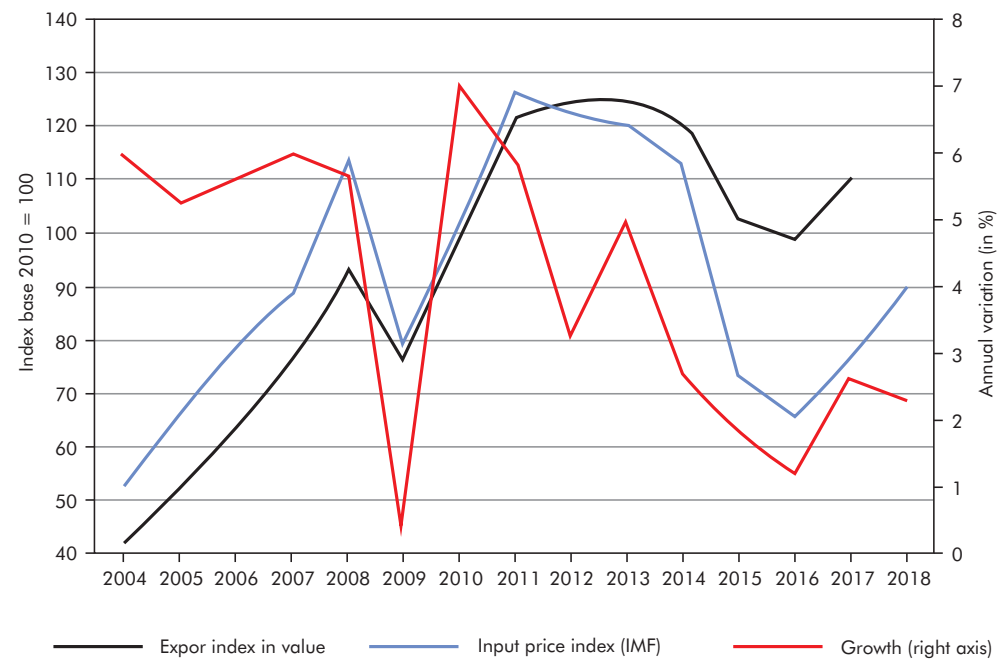

Note: Venezuela has been excluded due to the unavailability of data as of 2016 . The export value index is the average value of exports of goods and services in value for the nine South American countries considered with base 100 in 2010.

Source: Authors' elaboration based on CEPALSTAT, IMF World Economic Outlooks, World Bank Data, and own calculations.

6 Calculations used the price index of raw materials prepared by the IMF (IMF Primary Commodity Prices). This resulted in a fall in the implicit price of exports of goods and services of $14.5 \%$ between 2013 and 2017 for the average of the nine South American countries considered. The fall was greater in the case of hydrocarbon exporting countries such as Bolivia and Colombia (where it decreased on average by 29.3\%) and in countries with a high share of agricultural exports, such as Argentina, Brazil, Paraguay, and Uruguay (where the price fell on average 14.1\%). The decline was smoother in the exporting countries of metals such as Chile and Peru (average drop of 9.2\%).

7 To get an idea of the impact of the fall in international prices, between 2013 and 2018 South American exports (measured in value) fell on average 14.1\%, more than in the year 2009 when the international financial crisis broke out, and even that in the years 1998 and 1999. This decrease from the peaks reflected in the period 2010-2013 was widespread, with the exception of Peru, where exports continued to 2017. This is all based on CEPALSTAT, IMF Data and World Bank Data. 
Apart from the short-term influence of the evolution of international commodity prices at the level of activity in the region, what can be said about the dynamics of exported quantities? If there is no new boom in these prices, to what extent can these countries expand their level of activity given the pace - as we will see, mediocre - of real growth in their exports?

Over the past decade and a half, the typical Latin American concern for external growth restriction has, it could be said, taken to the background, given the favorable global context, which included strong growth in China, the high international price of raw materials, the low cost of indebtedness and high levels of liquidity in international financial markets. Excluding the international financial crisis of 2008-2009, this so-called "tailwind" remained until mid-2014 when international prices of raw materials fall and the structural restrictions on growth return to relevance. These restrictions were not shown more abruptly because, in most cases, there was fluid access to external financing that allowed to soften the impact of the fall in international prices of raw materials. In this section, we focus on the real restrictions and the following in those related to financing.

For the analysis of the limits to growth determined by the external sector with an emphasis on the real economy (productive specialization), the parameters of the socalled Thirlwall law are estimated as usual (THIRLWALL, 1979). According to this law, economic growth consistent with the external equilibrium of a country in the long term depends, given the rate of growth of trading partners, on the ratio between income and import income elasticities:

$$
y_{B t}=\frac{\varepsilon}{\pi} z_{t}
$$

In (1), $y_{B t}$ is the growth consistent with the external balance; $\varepsilon$ is the global income elasticity of exports; $\pi$ is the income elasticity of imports; and $z_{t}$ is the effective growth of the rest of the world.

In its original version, this law assumes that there is an initial trade balance and that the price effects are not relevant to the dynamics of exports and imports in the long term, and for that, it can be interpreted as the "ceiling" imposed by the external sector to the growth in a long-term economy. Its distinctive element is the quotient of elasticities of foreign trade, whose magnitude indicates the relative dynamics (of convergence of intelligence) of each economy concerning the world product.

Table 2 shows the estimates of the elasticities of foreign trade and their quotient for nine countries in South America for the period 1993-2017. ${ }^{8}$ The results reveal only in

8 Venezuela was not included in the estimates due to lack of data from 2015 onwards. 
two of the nine countries considered (Bolivia and Peru) the elasticity ratio was one or greater. This means that, for most countries in the region, if there is no change in their pattern of specialization, long-term growth will tend to be less than global growth.

Table 2 - South America (nine countries): estimated foreign trade elasticities, 1993-2017

\begin{tabular}{llll}
\hline & Income elasticity of exports & Income elasticity of imports & Elasticity coefficient \\
& $\varepsilon$ & $\pi$ & $\varepsilon / \pi$ \\
\hline Argentina & 1.1 & 2.8 & 0.4 \\
Bolivia & 1.4 & 1.3 & 1.1 \\
Brazil & 1.5 & 2.0 & 0.7 \\
Chile & 1.2 & 2.1 & 0.6 \\
Colombia & 1.1 & 2.1 & 0.6 \\
Ecuador & 1.0 & 1.6 & 0.6 \\
Paraguay & 0.8 & 1.5 & 0.6 \\
Peru & 1.6 & 1.6 & 1.0 \\
Uruguay & 1.2 & 1.7 & 0.7 \\
\hline
\end{tabular}

Note: estimates of the income elasticity of exports were made from exports and of world GDP at constant prices, and those of income elasticity of imports were made from imports and GDP of each country at constant prices. In the equation of imports, the quotient between the implicit price index of imports and GDP was introduced as a control variable, in those cases where the sign of the associated parameter was significant in economic terms (negative). All variables were included in logarithmic levels.

Source: Authors' elaboration based on CEPALSTAT, and World Bank Data.

Faced with a scenario such as the one described above, one shall question oneself about the dynamics of these structural parameters. In recent years, South American exports have slowed down more than the pace of world product growth, which reveals that (in general) low elasticities of the exports in Table 2 could continue to worsen. ${ }^{9}$ Figure 2 shows, precisely, a tendency to the fall of the income elasticity of exports and the elasticity ratio of foreign trade in the last two decades for most of the countries of South America. The only country that showed a slight improvement in the income elasticity of exports was Paraguay, where exports at constant prices maintained their growth despite the recessive episodes of the last five years of their main trading partners (Argentina and Brazil). So, the loss of export dynamism that can be seen in

9 In fact, based on CEPALSTAT, IMF World Economic Outlooks, and World Bank Data, the growth rate of exports at constant prices in South America fell from $7.9 \%$ in the $2004-2008$ period to just $1.4 \%$ in the 2014-2017 period, when global GDP growth decline was much less pronounced, from $4.9 \%$ to $3.5 \%$. In other emerging regions, such as Southeast Asia, export growth also fell significantly (from 10.2\% to 6.9\%) in the same periods, but remained at much higher levels. 
recent years in the region, and which is reflected in the general reduction in growth rates, is not only the exogenous product of the slowdown in international trade, as they tend to be emphasized in different analysis of the situation, but also the (more endogenous) effect of a backward movement or structural "uncoupling".

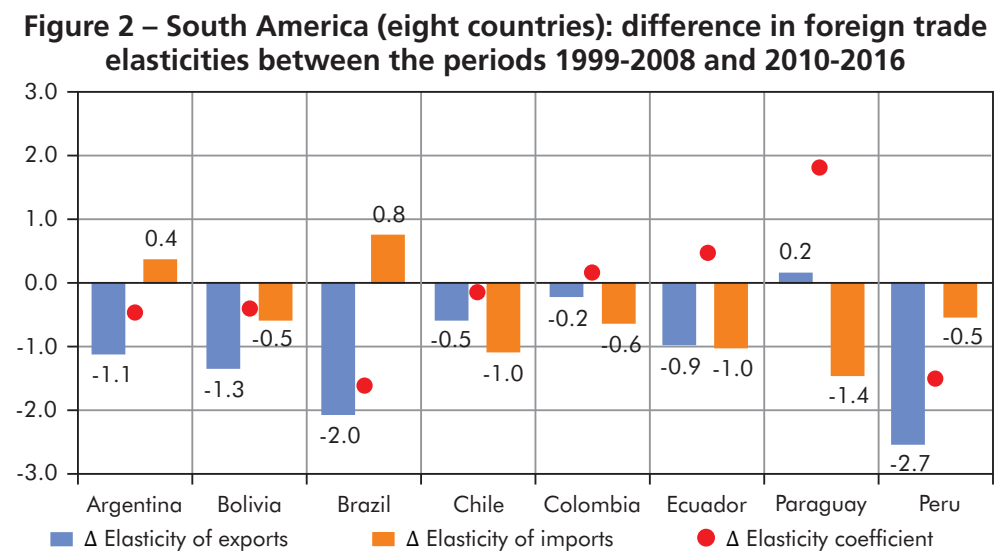

Source: based on estimates included in ECLAC (2018).

The elasticity ratio of foreign trade, or the Thirlwall coefficient, is associated with the type of productive specialization of each country. When reflecting the intensity of the stimulus to the aggregate demand originated in the exports (injections), as well as the depth of the leaks associated with the import flows (leakages), the analysis of its magnitude and evolution shows, as suggested by Setterfield (2011), a sort of "supplyside Keynesianism". We shall now analyze separately the dynamics of export and import elasticities.

In the case of the income elasticity of exports, the participation of sectors with greater Schumpeterian and Keynesian efficiency, more technologically intensive and with a more dynamic international demand (CIMOLI, PORCILE and ROVIRA, 2010), is particularly relevant. Empirical evidence shows that industrial manufactures, and especially those of high technological content, tend to have a greater income elasticity to world demand (DOSI, PAVITT and SOETE, 1990; ECLAC, 2007; GOUVEA and LIMA, 2010; CIMOLI, PORCILE and ROVIRA, 2010; CIMOLI and PORCILE, 2013), in contrast to exports of raw materials, whose participation in world trade has tended to fall in recent decades.

The low-income elasticity of South American exports contrasts with that of the countries of Asia, which in recent decades have shown remarkable economic growth driven by the high dynamism of their manufacturing exports. Figure 3 ahead shows how in South America the low-income elasticity of exports $(1,2)$ is associated with a low share 
of medium and high technology manufacturing in total manufacturing exports (21.8\%), in contrast with a set of countries in Southeast Asia ${ }^{10}$ where both variables tend to be higher (2.4 and 50.4\%, respectively), and even more so when compared with the countries of developed Asia, ${ }^{11}$ where the high-income elasticity of exports (3.0) is associated with a clear trade specialization in medium and high technology manufacturers (72\%).

Figure 3 - Income elasticity of exports and share of medium and high technology exports in total exports of manufactures by region, 1993-2017

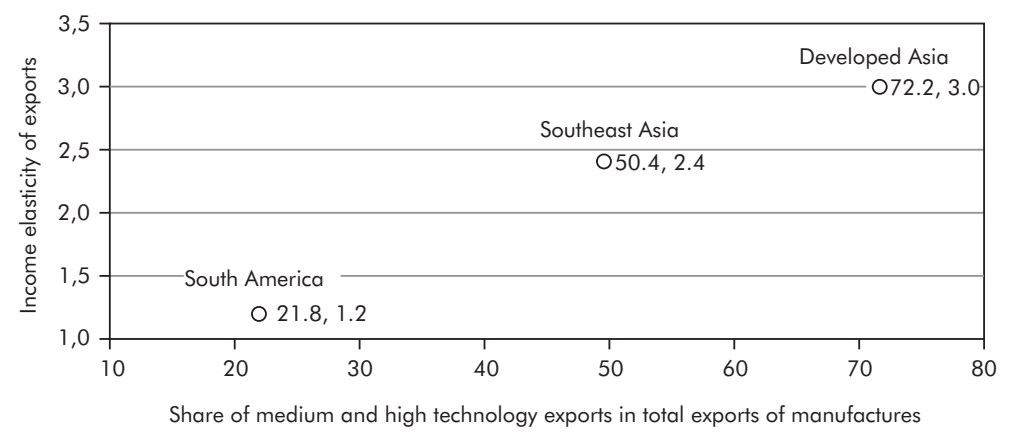

Note: Estimates were made based on exports and world GDP at constant prices, expressed in logarithmic level, and taking data with annual frequency. Fixed effects were included by country. The share of medium and high technology exports in manufacturing exports corresponds to the simple average for the period 1993-2015.

Source: Authors' elaboration and own estimates based on CEPALSTAT, World Bank Data, and IMF World Economic Outlooks.

The second element of the growth condition restricted by the balance of payments is the income elasticity of imports. This is determined by a wide range of factors, including in the first place the production structure of the country and its degree of insertion into global value chains. It is expected that greater productive diversification tends to reduce the elasticity of imports, based on the greater capacity of local supply to meet the internal demand for goods and services. Although, on the other hand, the greater integration into global value chains, which in recent decades characterized the most diversified economies, usually implies a greater propensity to import (intermediate goods).

Table 3 shows that there are no significant differences between the income elasticities of imports between across regions, despite the important differences in their production structures. The difference in the ratio of export and import elasticities of each region is essentially explained by export elasticities.

\footnotetext{
${ }_{10}$ Including Indonesia, Malaysia, the Philippines, Thailand, and Vietnam.

11 Including South Korea and Singapore.
} 
Table 3 - Elasticities of foreign trade by region, 1993-2017

\begin{tabular}{lccc}
\hline & Income elasticity of exports & Income elasticity of imports & Elasticity coefficient \\
\hline South America & 1.2 & 1.8 & 0.7 \\
Southeast Asia & 2.4 & 1.6 & 1.6 \\
Developed Asia & 3.0 & 1.4 & 2.1 \\
\hline
\end{tabular}

Note: estimates of the income elasticity of exports were made from exports and of world GDP at constant prices, and those of income elasticity of imports were made from imports and GDP of each country at constant prices. The quotient between the implicit price index of imports and GDP was introduced as a control variable in the import equation. All variables were expressed in logarithmic levels. Fixed effects by country were also included.

Source: Authors' elaboration and own estimates based on CEPALSTAT, World Bank Data, and IMF World Economic Outlooks.

The similarity between such different import elasticities hides international insertion patterns and forms that are very different from one another. These differences can be perceived quite clearly when analyzing separately the propensity to import from the different components of aggregate demand. For this, a regression of imports on exports and internal absorption expressed in logarithmic and standardized levels was made so that their parameters (beta coefficients) could become comparable. ${ }^{12}$ The results of the regression (Table 4) show that in South America imports are more sensitive to changes in internal absorption than to changes in exports, in contrast to Asian countries, where the response of imports to changes in exports is more intense. The greater sensitivity of the region's imports to internal absorption reflects its greater dependence on imports of final goods, given a less diversified production structure with difficulties in supplying local demand for a wide range of products, and in the process deindustrialization of the last decades. This greater sensitivity of imports to internal absorption raises the smallest margin in the region to promote a process of motorized growth by internal absorption, regardless of greater export thrust, or some form of import substitution.

Table 4 - Determinants of changes in the level of imports, 1993-2017

\begin{tabular}{lccc}
\hline Dep. Var.: Imports & South America & Southeast Asia & Developed Asia \\
\hline Constant & 1.31 & -5.1 & 3.95 \\
Exports & $0.57^{* * *}$ & $0.80^{*+*}$ & $0.71^{* * *}$ \\
Domestic absorption & $0.65^{* * *}$ & $0.22^{* * *}$ & $0.27^{* * *}$ \\
Relative prices & $-0.16^{* * *}$ & $-0.04^{* * *+}$ & $-0.03^{* * *+}$ \\
\hline
\end{tabular}

Note: the variables included in the regression were standardized to obtain their beta coefficients and make them comparable. The variable "relative prices" is the ratio between the implicit price index of imports and the implicit GDP index. Fixed effects by country were included. Legend: significance $\left(^{*}\right)$ at $10 \%,\left(^{* *}\right)$ at $5 \%$ and $\left({ }^{* * *}\right)$ at $1 \%$.

Source: Authors' elaboration and own estimates based on CEPALSTAT, and World Bank Data.

12 The quotient between the implicit price of imports and the implicit price of the product was also included as a control variable. 
The ratios of foreign trade elasticities presented in this section reflect the maximum growth rate compatible with the production structure of each country so as not to incur an unsustainable trade imbalance in the long term. On average (nine countries) that ratio is approximately 0.7 . This implies that if the weighted growth of South America's main trading partners was $2.8 \%{ }^{13}$ per year over the following five years, the region's growth could not exceed $2 \%$ per year (always on average).

Due to the sensitivity of the estimation of the elasticities of foreign trade, especially in the case of export elasticities, when estimating this type of "ceiling" or growth threshold, many authors choose to directly compute the variation of the exports in the numerator of Thirlwall's law $\left(\varepsilon Z_{t}=X_{t}\right)$. Given the low dynamism of the region's exports in recent years, if we consider the observed growth of exports of goods and services at constant prices between 2013 and 2017 (1.4\%) and the income elasticity of imports estimated previously $(1,8)$, the growth ceiling of the countries of South America would fall to only $0.8 \%$ (Thirlwall's condition " 2 " in table 6).

These growth ceilings are particularly low when considerations of population dynamics are incorporated. These are growth rates that, at best, would barely allow the vegetative growth of the active population to be absorbed, in economies with relatively low employment rates (ECLAC, 2018). If one considers that for each point of GDP growth employment grows at a rate of approximately half (employment-product elasticity of 0.5 ), and if a population growth projection of $1 \%$ per year is taken for the next five-year period, the growth necessary for the employment rate to remain stable in the region would be at least $2 \%$, similar to the first estimated growth ceiling (Thirlwall condition " 1 "), but much higher than the second, which incorporates the most recent dynamic of exports at constant prices (see Table 5). Also, these growth rates are insufficient to reduce the income gap compared to developed countries, taking the G7 countries as a reference, and assuming that their GDP per capita will grow by $1.1 \%$ annually in the next five years, the countries of the region must grow at least $2.1 \%$ annually, given the population growth rate of the countries of the region, so that the income gap or per capita regarding the G7 countries does not continue to expand.

The slowdown in growth experienced by the countries of South America in the last five years is not surprising in light of the structural limitations identified in this section. If the chock derived from the fall in international prices of raw materials since mid-2014 was not more serious, this is due to the fluid access to external financing that

\footnotetext{
13 Average growth projected by the IMF for the period 2019-2023 of the main trading partners of the region (China, United States, and European Union), weighted by the destination of exports of the nine countries considered for the period 2014-2017.
} 
in this period had the majority of the countries of the region, partly because of the improvement of the international investment position when the prices of raw materials boomed, and in part by a favorable international context characterized by high liquidity and low-interest rates. In the next section, we analyze how the momentary relief provided by external indebtedness may, if the production structure remains unchanged, lead to a lower limit ("ceiling") of growth even in the future.

\section{Table 5 - South America (nine countries): maximum and minimum rate of growth}

\begin{tabular}{|c|c|c|c|}
\hline \multicolumn{2}{|c|}{ Maximum rate of growth } & \multicolumn{2}{|c|}{ Minimum rate of growth } \\
\hline Thirlwall condition 1 & Thirlwall condition 2 & Employment threshold & Income threshold \\
\hline (1) & (2) & (3) & $(4)$ \\
\hline$y_{B t}=\frac{\varepsilon}{\pi} Z_{t}$ & $y_{B t}^{*}=\frac{X_{t}}{\pi}$ & $y^{E}=\frac{n}{\sigma}$ & $y^{I}=\left(1+y^{G 7}\right)(1+n)-1$ \\
\hline 2.0 & 0.8 & 2.0 & 2.1 \\
\hline
\end{tabular}

Note: The Thirlwall condition 2 considers the growth of exports of goods and services at constant prices for the 2014-2017 period, instead of the product between the income elasticity of exports and world growth. The employment threshold is the product growth rate that allows the employment rate to remain stable and considers an IMF projection of population growth in South America for the period 2019-2023 and an estimated employment-product elasticity for the period 2000-2016. The income threshold is the growth that allows to keep the income gap per capita constant for the most industrialized countries and considers a projection of average GDP growth per capita of the G7 countries and the population growth of South America for the period 2019-2023.

Source: Authors' elaboration based on own calculations.

\section{FROM EXPORT WEAKNESS TO DEBT SUSTAINABILITY}

The fall in exports (measured in value) of South America in the last five years has led the region to a situation of greater dependence on international financial markets, which was reflected in a rather significant increase in external indebtedness. According to ECLAC data, gross external debt in relation to GDP rose in general in these countries in the last five years, from an average of $30.9 \%$ in 2013 to $42.3 \%$ in 2018 (own calculation based on an estimate of ECLAC's debt stock and an estimate of the IMF's GDP in current dollars). ${ }^{14}$

Consequently, the external debt interest burden increased on average from $0.5 \%$ of GDP to $0.8 \%$ between 2013 and 2017 . The increase in the region's financial vulnerability is greater when considering the evolution of these variables in relation to exports in

${ }^{14}$ In the case of Bolivia, the increase in external indebtedness in recent years was matured by the decumulation of international reserves, which are still at high levels in terms of GDP. 
value, a measure of the ability to pay foreign currency commitments: external debt as a percentage of exports rose from an average of $131.8 \%$ in 2013 to $196.5 \%$ in 2018 (own calculation based on ECLAC estimates), and debt interest from $2.6 \%$ in 2013 to $4.7 \%$ in 2017.

Figure 4 - Gross external debt as a percentage of GDP

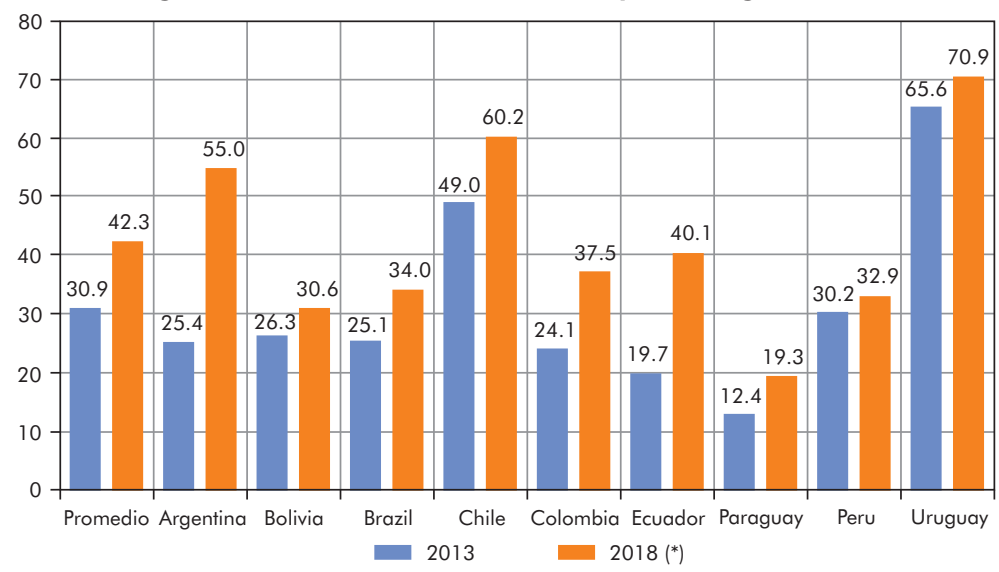

Source: Authors' elaboration based on CEPALSTAT.

The literature on growth restricted by the balance of payments has incorporated the possibility of access to external financing in its analytical framework, posing a condition of growth limited by an exogenous dynamic of external financing (THIRLWALL and HUSSAIN, 1982), or a condition of limited growth due to a stable relationship between the external deficit and GDP (MC COMBIE and THIRLWALL, 1995). In turn, Moreno-Brid $(1998,2003)$ incorporated an essential element for the study of peripheral countries, especially in Latin America, such as expenditures associated with the interests of external debt.

The growth condition raised in the previous section can be extended to incorporate the possibility of an initial external imbalance and the payment of interest on the debt, in line with Mc Combie and Thirlwall (1995) and Moreno-Brid (1998, 2003), ${ }^{15}$ with

15 Barbosa-Filho (2002) states that the condition of the expression (2) is not necessarily stable in the long term due to the mutual causal relationship between the growth rate and the level of imports. However, he argues that the evidence of the last decades for the region shows that the debt interest burden plays a significant role in external sustainability. 
the aim of evaluating the extent to which the growth ceiling may be more low in relation to the version that only considers trade flows.

$$
y_{B t}^{*}=\frac{\theta_{x} \varepsilon z_{t}-\theta_{r} r_{t}}{\pi-\left(1-\theta_{x}+\theta_{r}\right)}
$$

In (2), $r_{t}$ is the implicit interest rate of the external debt, $\theta_{x}$ and $\theta_{r}$ are the ratio between exports and interest on external debt, respectively, and imports.

Table 6 ahead reports the results of the estimation of the new growth condition (equation 2). As can be seen in column 2, in all countries considered the interest account of the net external debt is deficient, which reduces the growth condition ("ceiling"). However, as can be seen in column 5 compared to 4, the reduction in growth condition is insignificant. This is explained by the small relative size of these net flows in relation to the total volume of exports, whose weighting in the condition numerator is much greater. ${ }^{16}$

Table 6 - Growth condition with interest on external debt

\begin{tabular}{llcccc}
\hline & $\mathbf{X} / \mathbf{M}$ & $\mathbf{R} / \mathbf{M}$ & Implicit interest & $\begin{array}{c}\text { Conventional } \\
\text { Cond. }\end{array}$ & $\begin{array}{c}\text { Cond. with } \\
\text { Interest }\end{array}$ \\
& $\theta_{x}$ & $\theta_{r}$ & $r_{t}$ & $y_{t}^{* *}$ & $y_{t}^{* *}$ \\
\hline Argentina & 0.9 & -0.05 & 4.3 & 1.2 & 1.0 \\
Bolivia & 0.9 & 0.00 & 0.8 & 3.4 & 3.4 \\
Brazil & 1.0 & -0.05 & 5.3 & 2.3 & 2.2 \\
Chile & 1.0 & -0.02 & 1.5 & 1.7 & 1.7 \\
Colombia & 0.8 & -0.05 & 3.1 & 1.4 & 1.4 \\
Ecuador & 1.0 & -0.02 & 3.3 & 1.8 & 1.8 \\
Paraguay & 1.1 & -0.01 & 4.6 & 1.9 & 1.8 \\
Peru & 1.0 & -0.04 & 5.4 & 3.1 & 3.0 \\
Uruguay & 1.2 & -0.05 & 2.8 & 2.7 & 2.6 \\
Promedio & 1.0 & -0.03 & 3.46 & 2.0 & 1.9 \\
\hline
\end{tabular}

Source: Authors' elaboration and own estimates based on CEPALSTAT, World Bank Data, and IMF World Economic Outlooks.

16 The relatively low incidence of the inclusion of interest payments in the external growth restriction is in line with the conclusions reached by Setterfield (2011), who argues that financial flows have a negligible effect, always considering the long-term equilibrium conditions term. 
However, if the current account deficit stabilizes in terms of GDP (based on the growth rates estimated in Table 6), it does not imply that the resulting financing needs give rise to a dynamic of sustainable debt. In this regard, it is worth asking: what would be the indebtedness path of the next few years if this current account deficit and the foreign trade elasticities estimated above were maintained?

To answer this question, we begin by deriving a condition that establishes at what point the debt-to-GDP ratio would tend to stabilize, for a given current account balance and a certain long-term growth rate. The analysis of the dynamics and the level of the debt-to-GDP ratio is relevant because it is one of the variables that determine the possibility of access to international credit markets and their conditions. This is based on the condition that GDP $(Y)$ and the stock of external debt $(D)$ grow at the same rate $(y=d)$, where the debt growth rate is equivalent to the ratio between the current account deficit $(-C C)$ and the debt stock $(D)$.

$$
y=d \Rightarrow y=\frac{-C C}{D}
$$

It is then multiplied and divided by the level of GDP, and the debt-to-GDP ratio is cleared for a given current account deficit and a certain growth rate:

$$
y=\frac{-C C}{Y} \frac{Y}{D} \Rightarrow \frac{D}{Y}=\frac{-C C / Y}{y}
$$

Expression (4) establishes the level of equilibrium indebtedness for a given current account deficit and GDP growth rate. If South American countries had a growth rate of $2 \%$ in the coming years, in line with the conventional Thirlwall condition, and maintained an average current account deficit of $2.2 \%$, in line with the last five-year period, the gross external debt stock would tend to grow faster than GDP until the debtto-GDP ratio reached a level of $112.3 \%$, where it would stabilize. ${ }^{17}$ This level of equilibrium external debt is high in any historical and international comparison. ${ }^{18}$ This means that the level of hypothetical indebtedness to which the region would tend in the

17 This calculation does not consider FDI flows, which in some countries have a relevant weight. Including them in the estimation would imply contemplating the balance of net income flows and the net balance of new capital flows.

18 For example, the threshold estimated by the IMF (2002) for the external debt / GDP ratio based on episodes of debt crisis for its member countries (excluding the most industrialized advanced countries) for the period 1979-2001 is approximately 40\%. For those economies with a ratio of exports to GDP greater than $20 \%$, the indebtedness margin is greater, and the estimated threshold increases to 53\%. In South America, the countries in which the export / GDP ratio is greater than $20 \%$ are Bolivia, Chile, Ecuador, Paraguay, Peru, and Uruguay. 
long term, given the current conditions, does not seem sustainable in the light of historical experience, and that if there are no changes, it may involve financial difficulties or, as reflected in the recent dynamics, result in a greater economic slowdown.

Figure 5 - Simulation: growth rate of gross foreign debt and GDP

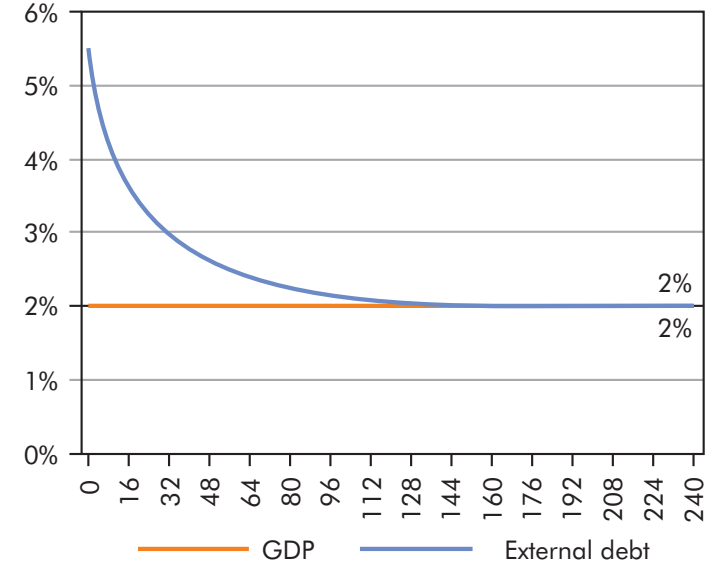

Note: This exercise assumes that the GDP growth rate is 2\% (estimated Thirlwall condition) and that the current account deficit as a percentage of GDP remains stable at $2.2 \%$. The horizontal axis refers to the number of periods (measured in years) from the initial moment.

Source: Authors' elaboration based on own calculations.

Figure 6 - Simulation: stock of gross external debt as a percentage of GDP

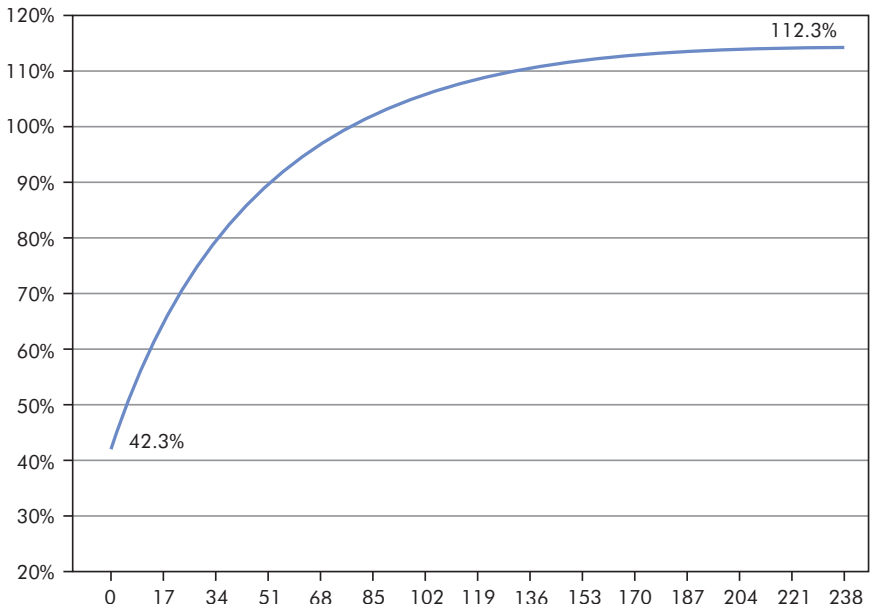

Note: This exercise assumes that the GDP growth rate is $2 \%$ (estimated Thirlwall condition) and that the current account deficit as a percentage of GDP remains stable at $2.2 \%$. The horizontal axis refers to the number of periods (measured in years) from the initial moment. Source: Authors' elaboration based on own calculations. 
Table 7 ahead shows the individual situation of each country. As can be seen in column 3, the indebtedness levels of Argentina, Bolivia, Brazil, Chile, Colombia, and Peru would also tend to increase exorbitantly in a hypothetical long term, reaching a level higher than $100 \%$ of GDP, given the rate of growth that arises from the conventional Thirlwall condition and the current account deficit levels of the 20142017 period. In all these cases, therefore, it is difficult to imagine an acceleration scenario. The exceptions are the cases of Ecuador, Paraguay, and Uruguay, where mainly from the low levels of initial account deficit, the debt-to-GDP ratio would tend to be reduced compared to current levels. This, however, without considering the flows of the financial account of the balance of payments, which in the case of some countries has had a central relevance. ${ }^{19}$

Table 7 - Gross external debt of long-term equilibrium

\begin{tabular}{lccc}
\hline & Thirlwall condition & Current account deficit & Debt/GDP (long term) \\
\hline & $(1)$ & $(2)$ & $(3)=(2) /(1)$ \\
Argentina & 1.2 & 3.0 & 246.4 \\
Bolivia & 3.3 & 4.0 & 121.2 \\
Brazil & 2.1 & 2.3 & 109.2 \\
Chile & 1.7 & 1.7 & 100.6 \\
Colombia & 1.7 & 4.8 & 288.9 \\
Ecuador & 1.9 & 0.4 & 20.5 \\
Paraguay & 1.7 & 0.1 & 8.3 \\
Peru & 3.0 & 3.3 & 109.2 \\
Uruguay & 2.2 & 0.5 & 20.9 \\
Promedio & 2.0 & 2.2 & 112.3 \\
\hline
\end{tabular}

Note: the current account balance data as a percentage of the GDP observed corresponds to the average for the 2014-2017 period.

Source: Authors' elaboration and own estimates based on CEPALSTAT, World Bank Data, and IMF World Economic Outlooks.

As stated in equation (4), the level of long-term equilibrium external indebtedness depends, on the one hand, on the balance of the current checking account and, on the other hand, on the growth ceiling established by the Thirlwall condition (which

19 In the case of Ecuador, a potential source of financial vulnerability is the formation of external assets of the private sector observed in recent years, and in the case of Uruguay, foreign currency deposits of nonresidents in the local financial system. 
ensures that the current checking account balance does not deteriorate). ${ }^{20}$ This relationship raises two alternatives to avoid the trend of growing external indebtedness: (i) a reduction in the current account deficit at the starting point, or (ii) a structural change that increases the elasticity ratio of foreign trade.

Without a change in the elasticities of foreign trade, and given the pace of global growth, the first alternative necessarily implies a reduction in the level of imports and income. That is a recession or several years of low growth, even less than the ceilings estimated in this section and the previous one. This seems to be the path followed by the largest countries in the region (Argentina ${ }^{21}$ and Brazil), where the difficulties of the external sector together with local political conflicts led to a contraction in their level of income and their imports, with a deterioration of the social conditions and with a damage to its productive sectors. The rest of the countries in the region, among which are Bolivia, Chile, Colombia, Ecuador, Paraguay, and Uruguay, adjusted their growth downwards to a lesser extent, partly due to the greater external slack provided by their greater exports of natural resources per capita, and partly because of the access to international markets that the latter enables.

\section{CONCLUSIONS}

The economies of South America experienced a sharp slowdown in the last five years (2014-2018). Even excluding the countries that performed poorly in that period (Argentina, Brazil, and Venezuela) the fall in the pace of economic growth of recent years is very significant: an average of 5.5\% in 2004-2008 and 5.6\% in 2010-2013 to 2.9\% in 2014-2018. This calculation includes Bolivia and Paraguay, the economies with the best recent relative performance, without which the average growth of the last five years would have been even lower (1.8\%, always excluding Argentina, Brazil, and Venezuela). In any case, it is a rate of expansion that barely exceeds that of the population and is well below that required by the economies of the region to close their income gap with developed countries. ${ }^{22}$ In this paper, we have tried to show how from the perspective of a thinker like Raúl Prebisch this tendency to "fly low" was predictable

20 See Barbosa-Filho (2002) for a more detailed analysis of the factors that determine a sustainable dynamics of external indebtedness.

${ }^{21}$ In the case of Argentina, external indebtedness had a strong recent increase that allowed sustaining income levels until the beginning of 2018.

22 Bolivia, Paraguay and Peru were the only countries that reduced their income gap in relation to, for example, the United States, between 2014 and 2018. 
and that, if the prevailing institutional arrangements and the resulting set of economic policies were maintained, the low growth rates recently observed would persist.

The weight of natural resources in the export basket of South American countries (which worried Prebisch so much) increased in the last 15 years, even though industrial policy recovered part of the land lost, especially compared to the time when Latin American governments themselves repeated the motto that "the best industrial policy is to have no industrial policy." The weight of natural resources in the export basket of South American countries (which worried Prebisch so much) increased in the last 15 years, even though industrial policy recovered part of the land lost, especially compared to the time when governments themselves repeated the motto that "the best industrial policy is to have no industrial policy". Thus, despite (or perhaps due to) the external slack derived from the boom in international prices of raw materials in the 2000s, these countries have not managed to develop new technological capacities and achieve greater diversity in production (even within the aforementioned trend to the reprimarization), as other economies with strong weight of the natural resources that usually are mentioned like models to follow (Australia, Canada, New Zealand).

The relative weakening of the productive capacities of South American countries can be seen in the evolution of the structural parameters of their foreign trade. As discussed in section 1, the maximum growth rate consistent with the long-term external equilibrium (estimated according to Thirlwall's law, based on the ratio between world income elasticity of exports and income elasticity of imports of each country), averaged between $0.8 \%$ and $2 \%$ per year according to the estimation methodology. It is a pace of expansion that, together with the most optimistic estimate, barely reaches the growth rate necessary to absorb the vegetative growth of the population. ${ }^{23}$ This not only rules out, in the absence of an effective policy of structural change, any possibility of converging with developed economies but also reveals the difficulty to achieve a much more modest objective: to avoid widening the gap between these economies and economies of the region.

Thirlwall's condition postulates a long-term threshold or limitation. It does not exclude the possibility that this threshold will be exceeded in the short or mediumterm as a result of, for example, improvements in the terms of trade, or through access to external financing. The first variant (an improvement in the terms of trade) is what made the "overgrowth" of the 2004-2008 period possible, while fluid access to external financing, in a context of high international liquidity, is what allowed the "overgrowth" of the most recent period when there is a slower pace of expansion than the one before

${ }^{23}$ Estimated based on population growth and employment-product elasticity of each economy. 
the international financial crisis of 2008-2009, but greater than that - if such financing does not exist - the existing structural restrictions would be imposed.

Access to external financing, which makes it possible to soften the blow of a fall in terms of trade or postpone the impact of weak export performance, can have negative effects in the medium or long term. If resources from abroad are not applied to the reversal of structural limitations, the growth rate consistent with the long-term external equilibrium will tend to decrease over time. Prebisch was aware of these types of sequels, which could derive from indiscriminate access to external financing, although in the context of strong regulation of international financial flows during the postwar period, he associated this type of financing almost exclusively with direct foreign investment.

It cannot be denied that the economic development of certain Latin-American countries and their rapid assimilation of modern technology, in so far as they can utilize it, depend to a very large extent upon foreign investment. The implications involved render the problem far from simple. The negative factors include the failure to meet foreign financial commitments during the great depression of the nineteen thirties, a failure which, it is generally agreed, must not be allowed to happen again. Fundamentally the problem is the same as that referred to in the preceding paragraph. The servicing of these foreign investments, unless new investments are made, must be paid for by means of exports in the same currency and, if these do not show a corresponding increase, in time the same difficulties will arise again. They will be the greater if exports fall violently. The question thus arises whether, pending that basic solution, it would not be wiser to direct investments toward such productive activities as would, through direct or indirect reduction of dollar imports, permit the regular servicing of foreign obligation. (PREBISCH, 1950, p. 4-5)

Precisely to capture this type of complication in section 2 we incorporated the interests of the external debt to the estimation of the growth threshold consistent with the external balance, to obtain a more comprehensive representation (real and financial) of the factors that can restrict Long term growth. This led us to the analysis of the dynamics of external indebtedness and its sustainability. What emerges more clearly when introducing the "stock restrictions" is the enormous economic cost (measured in terms of growth) that involves maintaining the productive structure unaltered. From the analysis carried out in that section, it follows that, if the characteristics of its commercial insertion do not change profoundly, given the current account deficits that it has exhibited in recent years, most of the South American countries must grow below the necessary rate to absorb the vegetative growth of its 
population if they want to avoid an unsustainable trajectory of their debt. The proliferation of mediocre growth rates such as those experienced in recent years, and the difficulty in glimpsing a different horizon, can be better understood in the context of this double constraint (real and financial).

\section{REFERENCES}

ABELES, M.; CALDENTEY, E. P.; VALDECANTOS, S. (Eds.). Estudios sobre fnanceirización en América Latina. (Libros de la CEPAL, n. 152). Santiago de Chile: CEPAL, 2018.

BARBOSA-FILHO, N. H. The balance of payments constraint: from balanced trade to sustainable debt. New York: Center for Economic Policy Analysis (CEPA), 2002.

BASTOURRE, D.; ZEOLLA, N. Regulación de la cuenta capital en un mundo financieramente complejo: evolución reciente y perspectivas en América Latina. (Serie Estudios y Perspectivas-Oficina de la CEPAL en Buenos Aires, n. 52). Santiago de Chile: CEPAL, 2017.

CAVALLO, E.; POWELL, A. (Coords.). La hora del crecimiento. Informe macroeconómico de América Latina y el Caribe de 2018. Washington, DC: Banco Interamericano de Desarrollo, 2018.

CIMOLI, M.; PORCILE, G. Technology, structural change and BOP-constrained growth: a structuralist toolbox. Cambridge Journal of Economics, v. 38, n. 1, p. 215-237, 2013.

CIMOLI, M.; PORCILE, G.; ROVIRA, S. Structural change and the BOP constraint: why did Latin America fail to converge? Cambridge Journal of Economics, v. 34, n. 2, p. 389-411, 2010.

DOSI, G.; PAVITT, K.; SOETE, L. The economics of technical change and international trade. Brighton: Wheatsheaf, 1990.

ECLAC - ECONOMIC COMMISSION FOR LATIN AMERICA AND THE CARIBBEAN. CEPALSTAT [On-line] Available at: <https://estadisticas.cepal.org/cepalstat/Portada.html>

ECLAC - ECONOMIC COMMISSION FOR LATIN AMERICA AND THE CARIBBEAN. Progreso técnico y cambio estructural en América Latina. Santiago de Chile: ECLAC, October 2007.

ECLAC - ECONOMIC COMMISSION FOR LATIN AMERICA AND THE CARIBBEAN. La hora de la igualdad: brechas por cerrar caminos por abrir. Santiago de Chile: ECLAC, 2010.

ECLAC - ECONOMIC COMMISSION FOR LATIN AMERICA AND THE CARIBBEAN. Cambio estructural para la igualdad: una visión integrada del desarrollo. Santiago de Chile: ECLAC, 2012.

ECLAC - ECONOMIC COMMISSION FOR LATIN AMERICA AND THE CARIBBEAN. La ineficiencia de la desigualdad. Santiago de Chile: ECLAC, 2018.

ECLAC - ECONOMIC COMMISSION FOR LATIN AMERICA AND THE CARIBBEAN. Panorama social de América Latina, 2018. Santiago de Chile: ECLAC, 2019.

GOUVEA, R. R.; LIMA, G. T. Structural change, balance of payments constraint and economic growth: evidence from the multi-sectoral Thirlwall's Law. Journal of Post Keynesian Economics, v. 33, n. 1, p. 169-204, October 2010. 
IMF - INTERNATIONAL MONETARY FUND. Assessing sustainability. Washington, DC: IMF, 2002.

IMF - INTERNATIONAL MONETARY FUND. IMF Outlook Reports. [On-line] 2019. Available at: <https://www.imf.org/en/Publications/WEO>

IMF - INTERNATIONAL MONETARY FUND. IMF primary commodity prices. [On-line] 2019. Available at: <https://www.imf.org/en/Research/commodity-prices>

OCAMPO, J. A.; PARRA, M. A. Los términos de intercambio de los productos básicos en el siglo XX. Revista de la CEPAL, n. 79, p. 7-35, 2003.

PREBISCH, R. El desarrollo económico de la América Latina y sus principales problemas. Santiago de Chile: ECLAC, 1949.

PREBISCH, R.; UNIES, N. The economic development of Latin America, and its principal problems [by Pr. Raul Prebisch, October 1949]. NY, 1950.

SETTERFIELD, M. The remarkable durability of Thirlwall's Law. PSL Quarterly Review, v. 64, n. 259, p. 393-427, 2011.

THIRLWALL, A. The balance of payments constraint as an explanation of the international growth rate differences. PSL Quarterly Review, v. 32, n. 128, 1979.

THIRLWALL A. P.; HUSSEIN M. N. The balance of payments constraint, capital flows and growth rate differences between developing countries. Oxford Economic Papers, v. 34, p. 498-510, 1982.

MC COMBIE, J.; THIRLWALL, A. P. Economic growth and the balance-of-payments constraint revisited. Department of Land Economy, 1995.

MORENO-BRID J. C. On capital flows and the balance-of-payments-constrained growth model. Journal of Post Keynesian Economics, v. 21, p. 283-298, 1998.

MORENO-BRID, J. C. Capital flows, interest payments and the balance-of-payments constrained growth model: a theoretical and empirical analysis. Metroeconomica, v. 54, n. 2-3, p. 346-365, 2003.

WORLD BANK . World Bank Data. [On-line] Available at: <https://data.worldbank.org/> 


\section{APPENDIX}

Table A.1. South America (10 countries): growth rates, 2004-2018 (in percentages, simple average)

\begin{tabular}{|c|c|c|c|}
\hline Countries & 2004-2008 & 2010-2013 & 2014-2018(*) \\
\hline Argentina & 7.8 & 4.4 & -0.3 \\
\hline Bolivia & 4.8 & 5.3 & 4.6 \\
\hline Brazil & 4.8 & 4.1 & -0.8 \\
\hline Chile & 5.5 & 5.3 & 2.1 \\
\hline Colombia & 5.4 & 5.0 & 2.8 \\
\hline Ecuador & 5.3 & 5.5 & 1.2 \\
\hline Paraguay & 4.6 & 5.8 & 4.2 \\
\hline Peru & 7.3 & 6.7 & 3.2 \\
\hline Uruguay & 5.9 & 5.3 & 2.0 \\
\hline Venezuela & 10.5 & 2.4 & -11.1 \\
\hline South America & 6.2 & 5.0 & 0.8 \\
\hline South America (except Venezuela) & 5.7 & 5.3 & 2.1 \\
\hline South America (except Argentina, Brazil and Venezuela) & 5.5 & 5.6 & 2.9 \\
\hline
\end{tabular}

Note: $\left(^{*}\right)$ for the year 2018, the ECLAC projections published in December 2018 were considered.

Source: Authors' elaboration and own estimates based on CEPALSTAT, World Bank Data, and IMF data. 